Vol. 15 (2006): 444-458.

\title{
Managing Sonchus arvensis using mechanical and cultural methods
}

\author{
Petri Vanhala \\ MTT Agrifood Research Finland, Plant Protection, FI-31600 Jokioinen, Finland, e-mail: petri.vanhala@mtt.fi \\ Timo Lötjönen \\ MTT Agrifood Research Finland, Plant Production, FI-92400 Ruukki, Finland \\ Timo Hurme \\ MTT Agrifood Research Finland, Information Management, FI-31600 Jokioinen, Finland \\ Jukka Salonen \\ MTT Agrifood Research Finland, Plant Protection, FI-31600 Jokioinen, Finland
}

\begin{abstract}
Perennial sow-thistle (Sonchus arvensis L.) represents an increasing problem in Finland. Options for mechanical and cultural control of $S$. arvensis were studied in a field experiment on clay soil under organic production. The experiment consisted of different crop sequences: spring cereal (barley, Hordeum vulgare L., in 2001, oats, Avena sativa L., in 2002) with or without inter-row hoeing and/or stubble cultivation, bare fallow, fibre hemp (Cannabis sativa L.), and ley with mowing. In 2003 the entire field was sown to spring wheat. Crop plant and Sonchus shoot density and dry mass prior to cereal harvest and crop yield were assessed. The control effect was rated: bare fallow $>$ ley $>$ cereal with or without inter-row hoeing $>$ poor growth fibre hemp. Bare fallow was an effective but costly way to reduce S. arvensis infestation. Introduction of a regularly mown green fallow or silage ley in the crop rotation is advisable. Mechanical weed control by inter-row hoeing in cereals limits $S$. arvensis growth. Infestation might also be reduced by stubble cultivation in autumn. When managing $S$. arvensis using mechanical and cultural methods, appropriate options, including a competitive crop, should be chosen for the specific field and rotation.
\end{abstract}

Key-words: perennial weeds, Sonchus arvensis, perennial sow-thistle, mechanical control, crop rotation, tillage, inter-row hoeing

\section{Introduction}

Perennial weeds, including perennial sow-thistle (Sonchus arvensis L.), are becoming increasingly problematic in Finland, particularly in organic farming (Salonen et al. 2001a, Salonen and Hyvönen 2002). Managing S. arvensis using nonchemical (mechanical and cultural) methods is not easy. However, crop competition and cultural 
Vol. 15 (2006): 444-458.

practices, including mowing, hoeing and bare fallowing, provide some possibilities for managing $S$. arvensis. Information on the response of $S$. arvensis to various physical and cultural control measures is a prerequisite for successful management.

S. arvensis is found throughout the temperate regions of the world (Holm et al. 1997). In Finland it is slightly more common than creeping thistle [Cirsium arvense (L.) Scop.] (Salonen et al. 2001b). Propagation of S. arvensis occurs both vegetatively by roots and generatively through seeds. Vegetative sprouts start to emerge in spring when the soil begins to warm up (Håkansson 1969). The rate of emergence and number of emerging sprouts is related to the amount of dry matter in the roots (Lemna and Messersmith 1990). S. arvensis reaches the compensation point, i.e. the minimum level of root reserves, at 5-7 leaves (Håkansson 1969). The roots may grow 0.5-2.8 meters in a year (Lemna and Messersmith 1990), thus making the plant very capable of spreading vegetatively. Most $S$. arvensis spreading roots grow in the top $10 \mathrm{~cm}$ of soil, although some grow down to $25 \mathrm{~cm}$ (Holm et al. 1997) and are thus subject to mechanical disturbance by tillage. Viability of roots cut through tillage is reduced. Small root fragments are less viable than large ones. However, even sections shorter than $2.5 \mathrm{~cm}$ can generate new plants (Lemna and Messersmith 1990, Holm et al. 1997).

Autumn tillage is expected to have less effect on S. arvensis than on Elymus repens (L.) Gould (common couch), as $S$. arvensis falls into dormancy early in the autumn (Håkansson 1969, Håkansson and Wallgren 1972, Fogelfors et al. 2003). Nonetheless, the fragmentation of roots and their burial weakens the competitive capacity of the plants to some extent during the following growing season (Gummesson 1992, Håkansson 1995). According to Mukula (1974), S. arvensis competes strongly against cereals. Notwithstanding, competitive crops with vigorous early growth might be an option to reduce the deleterious effects of $S$. arvensis, as young plants in particular are sensitive to competition for light (Zollinger and Kells 1991). The more $S$. arvensis plants suffer from light dep- rivation, the less they are able to accumulate assimilates in roots (Zollinger and Kells 1991).

However, even though there are several sowthistle management methods of varying efficiency, there is no single solution suitable for all situations, production orientations and crop rotations. Therefore, it would be profitable if there were several alternatives for $S$. arvensis control to suit any given situation. Despite several studies done on $S$. arvensis biology and control, little research has been done under field conditions, comparing the immediate and resultant effects of several nonchemical options for S. arvensis control. Our study aimed to fill this gap in knowledge.

The aim of this study was to establish nonchemical methods for managing $S$. arvensis, particularly for organic cropping. The objectives were to 1) study the effect of crop, mechanical weed control and other management on S. arvensis density and biomass, during the same growing season and in the following year(s), 2) study crop yield under different treatments, as affected by the treatments directly and through $S$. arvensis infestation (and other weeds) indirectly, and 3) document the labour input associated with different control methods, and finally 4) provide some recommendations for crop rotations.

\section{Material and methods}

A three-year field experiment was set up in 2001 at Vihti, southern Finland (60 $27^{\circ} \mathrm{N} ; 2^{\circ} 21^{\prime}$ E). It was done on a clay soil (containing 6-12\% organic matter), infested with Cirsium arvense, Elymus repens and Stachys palustris L. (marsh woundwort), and heavily infested with $S$. arvensis. The field was flat and often moist due to the high ground water level. S. arvensis is known to prefer clay soils (Holm et al. 1997) and moist conditions (Zollinger and Kells 1991). The field had been in organic production since 1997. The previous crop in 2000 was spring wheat (Triticum aestivum L.). In 2000 weeds were controlled by inter-row hoeing once. 
Vanhala, P. et al. Managing Sonchus arvensis using mechanical and cultural methods

The experiment had seven treatments (see Table 1) and two levels of stubble cultivation (yes/ no) organized in a strip-plot design with five replicate blocks. The blocks were positioned so that the prior weed infestation was as uniform as possible within each block. Stubble cultivation and treatment strips were randomized separately in each block. The plot size was $3 \mathrm{~m} \times 25 \mathrm{~m}$, but for fibre hemp (Cannabis sativa L.) it was $5 \times 25 \mathrm{~m}$. In 2003 the entire experimental area was sown to spring wheat to establish the resultant effects of the treatments. In 2003 no weed control was done.

\section{Rationale for the treatments chosen, and comparisons made}

The experimental factors were chosen for the following reasons: cereal without weed control (Cer) as a standard crop to compare among effects of inter-row hoeing $(\mathrm{H})$, stubble cultivation and bare fallowing (Bf) (mechanical control), fibre hemp to have a crop of different competitive ability to cereals, and ley to include a crop that is mown. The effects of different methods were examined by comparisons within the following groupings. (1) Treatment $\times$ stubble cultivation interaction: the dependence of treatments $\mathrm{Cer}$, CerH and Cer-Bf in 2002 and Cer, CerH and Bf-Cer in 2003 from stubble cultivation (Cer as reference). (2) Comparisons between treatments that were not stubble cultivated: in 2001 all the treatments (Cer as reference), in 2002 treatments Hemp, Cer-Ley, Bf-Cer and Ley (Hemp as reference), and in 2003 treatments Hemp, Cer-Bf, Cer-Ley and Ley (Hemp as reference). (3) Furthermore, in 2002 and 2003 the standard crop Cer was compared with the treatments for which stubble cultivation was not applied, in 2002 Hemp, Cer-Ley, Bf-Cer and Ley and in 2003 Hemp, Cer-Bf, Cer-Ley and Ley, using only data from the horizontal strip that was not stubble cultivated.

Each year the cropping practice (with cereals and fibre hemp) was: autumn ploughing - level harrowing - S-tine harrowing - slurry spreading - S-tine harrowing/ rotary harrowing - drilling (trailing shoe coulters) - harvesting - stubble-cultivating (if included). The whole experiment field was fertilised every spring with pig slurry (60-100 $\mathrm{kg} \mathrm{N}_{\text {soluble }} \mathrm{ha}^{-1}$ ) applied using a band spreader. The plots were drilled every year between 16-27 May.

Table 1. The treatments during the years 2001-2003.

\begin{tabular}{llclc}
\hline $\begin{array}{l}\text { Abbreviation of } \\
\text { treatment }{ }^{1}\end{array}$ & Year 2001 & $\begin{array}{l}\text { Sc in autumn } \\
2001^{2}\end{array}$ & Year 2002 & $\begin{array}{l}\text { Sc in autumn } \\
2002^{2}\end{array}$ \\
\hline Cer & Barley 'Pohto' & sc & Oats var. 'Aslak' & sc \\
CerH & Barley + hoeing & sc & Oats + hoeing & sc \\
Cer-Ley & Barley with undersown ley & - & Ley & - \\
Ley & Ley & - & Ley & - \\
Bf-Cer & Bare fallow & - & Oats & sc \\
Cer-Bf & Barley & sc & Bare fallow & - \\
Hemp & Fibre hemp 'Fedora 17' & - & Fibre hemp & - \\
\hline
\end{tabular}

In 2003 spring wheat 'Anniina' was grown in all plots

1 The treatments remained at the same locations throughout the experiment.

${ }^{2} \mathrm{Sc}$ indicates treatments in which stubble cultivation was applied after harvest as a factor (counted as treatment in following year's assessments). One end of these plots was stubble cultivated while the other end was not stubble cultivated. 
Vol. 15 (2006): 444-458.

\section{Individual treatments}

Treatment Cer stood for normal cereal cultivation without weed control. The seed rate for barley (Hordeum vulgare L.) in 2001 was 500 viable seeds per $\mathrm{m}^{2}$, in 2002 for oats (Avena sativa $\mathrm{L}$.) 550 viable seeds per $\mathrm{m}^{2}$ and in 2003 for spring wheat 750 viable seeds per $\mathrm{m}^{2}$. The row spacing was $12.5 \mathrm{~cm}$. Treatment CerH used the same seed rates, but the row spacing was $18.0 \mathrm{~cm}$ for interrow hoeing (except in 2003). Inter-row hoeing was done 3 times in 2001 (barley growth stages: 3 leaves, tillering, and half of inflorescence emerged) and twice in 2002 (oats growth stages: 2 leaves, and tillering-first node). The principle of the interrow hoe is described by Lötjönen and Mikkola (2000). The cereal plots were combine harvested at the end of August or during the beginning of September.

Fibre hemp (Hemp) was included, because it is a very tall crop and it was assumed to compete well against perennial weeds. The seed rate was 30 $\mathrm{kg} \mathrm{ha}^{-1}$ (approximately 170 seeds per $\mathrm{m}^{2}$ ) and no weed-control was applied during the summer in this crop. As the stem yield was poor and hemp stems were mixed with substantial amounts of $S$. arvensis and other weeds, the hemp stems were not harvested, but the plants were crushed in the field during the end of October in both years.

In treatment Cer-Ley the red clover (Trifolium pratense L.) - timothy (Phleum pratense L.) ley was established with cover crop (barley) and in treatment Ley without a cover crop. The drilling was done through trailing shoe coulters with $7 \mathrm{~kg}$ $\mathrm{ha}^{-1}$ red clover and $13 \mathrm{~kg} \mathrm{ha}^{-1}$ timothy seed. The ley in treatment Ley was mown three times with a rotary flail mower in 2001, mainly to control weeds. The cut foliage of ley was left on the field. In 2002 both leys (Cer-Ley and Ley) were mown three times with a cutter-bar mower and the cut foliage was removed from the plots.

Treatments Bf-Cer and Cer-Bf contained bare fallow but in different years (Table 1). Bare fallow was cultivated with an S-tine harrow (seedbed cultivator) always when $S$. arvensis reached 5-7 leaves (6-7 times per summer). This represented an attempt to exhaust the carbohydrate reserves in

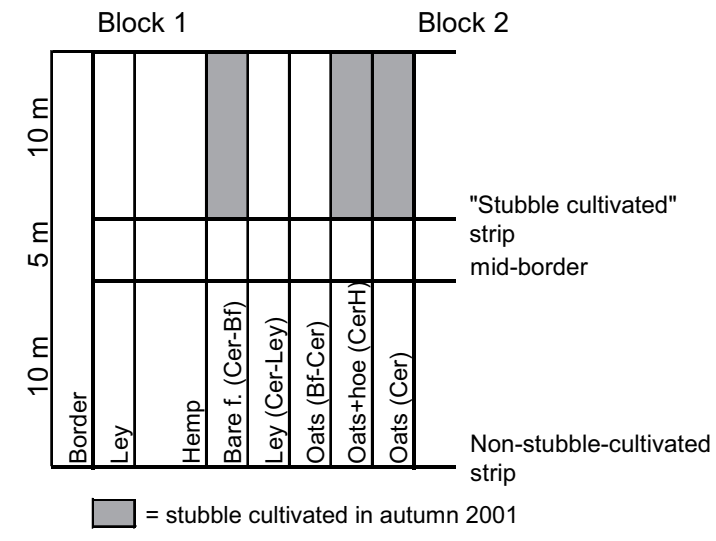

Fig. 1. Experimental layout, example: block 1 in 2002.

the weed roots. The experimental plots were so narrow $(3 \mathrm{~m})$ that crosswise harrowing was not possible. Hence the weed control effect of harrowing was not as good as it could have been under actual field conditions.

Half of the cereal plots were stubble-cultivated twice with an S-tine harrow after harvesting (Fig. 1). All cereal plots and fibre hemp plots were ploughed in the autumn.

The weather was slightly warmer during the 2001-2003 growing seasons compared with the 1975-1995 average (Finnish Meteorological Institute 2004). Summer 2002 was particularly warm. In 2001 the rainfall was higher and in 2003 lower than average. Compared with the average monthly rainfall levels, those for September 2001, June 2002 and May 2003 were particularly high.

\section{Assessments}

Prior to cereal harvest, weed and crop plant samples from 2 quadrats $(0.5 \mathrm{~m} \times 0.5 \mathrm{~m})$ per plot (one from each horizontal strip) were cut at the soil surface. The placement of the quadrats was near one end of each plot, alternating the end between years (i.e. sampling in 2003 was done closer to sampling in 2001 than that done in 2002). The sampling 
Vanhala, P. et al. Managing Sonchus arvensis using mechanical and cultural methods

quadrats in the hoed plots in 2001 and 2002 were partially on the wide inter-row space on tractor wheel tracks, so there were only two crop rows within the quadrats. The shoot density of $S$. arvensis, other weeds, and crop plants was assessed, and their biomass was determined after air-drying in an air-flow drier at $40^{\circ} \mathrm{C}$ for several days. The yields of leys and cereals were harvested and recorded from areas of $13-38 \mathrm{~m}^{2}$ and $15-50 \mathrm{~m}^{2}$, respectively.

\section{Statistical methods}

The experiment was organized in a strip-plot design (see e.g. Milliken and Johnson 1984, Gomez and Gomez 1984) with stubble cultivation as a horizontal factor and treatment as a vertical factor, i.e. for each block stubble cultivation (yes/no) was randomized to divide the block into two horizontal strips, and treatments were randomized to divide the block into seven vertical strips. However, in 2001 stubble cultivation was not applied prior to assessments. Therefore, a mean over the two strips of stubble cultivation was calculated and the means were analyzed as a traditional randomized complete block design. Data for 2002 and 2003 were analyzed as a traditional strip-plot design:

$$
Y_{i j k}=\mu+s_{k}+\alpha_{i}+h_{i k}+\beta_{j}+v_{j k}+\gamma_{i j}+\varepsilon_{i j k},
$$

where $\mu$ is constant and $\alpha_{i}, \beta_{j}$ and $\gamma_{i j}$ are the horizontal (stubble cultivation) and vertical (treatment) factors and their interaction, respectively. $h_{i k}$ and $v_{j k}$ are the error terms associated with stubble cultivation and treatment, respectively. $s_{k}$ denotes the block effect, and $\varepsilon_{i j k}$ is the error term associated with a cell experimental unit, which is the horizontal-vertical intersection. All the error terms and the block effects were assumed to be independent and normally distributed with zero means and variances $\sigma_{h}^{2}, \sigma_{v}^{2}, \sigma_{\varepsilon}^{2}$ and $\sigma_{s}^{2}$ (Milliken and Johnson 1984).

In 2002 and 2003 stubble cultivation was applied only on three treatments, each year. Due to this unorthodox arrangement the effects of the horizontal factor, vertical factor and their interaction had to be examined using pairwise compari- sons among treatments instead of F-tests, i.e. the comparisons were done separately for the treatments for which stubble cultivation was applied and for the treatments for which stubble cultivation was not applied. Density and biomass of $S$. arvensis, the yield and density of cereals and crop biomass were analyzed using the strip-plot model specified above.

Ley yield was analyzed only in 2002, when there were two ley treatments. It was analyzed as a traditional randomized complete block design with repeated measurements: the ley yields measured from the same experimental plot at the times of the three mowings were considered to be the repeated measurements. The correlation between these repeated measurements was taken into account by using a compound symmetry covariance structure.

The models were fitted for data using PROC MIXED of the SAS System version 8.2. (SAS Institute Inc. 1999). For all the models mentioned above REML was used as an estimation method. Pairwise comparisons were performed using twosided t-type tests. Type I error was controlled by limiting the number of comparisons as much as possible, testing only those pairs that were of interest in light of the hypotheses for this study. Therefore, the number of pairwise comparisons varied among analyses of different response variables. Model assumptions were checked graphically. Examination of the model residuals revealed two outliers for the biomass of S. arvensis; one in 2001 and one in 2003, as well as one for the density of S. arvensis in 2003. Because no explanation was found for the outliers the data were analyzed with and without them. For biomass and density of $S$. arvensis in 2002 and 2003 a square root transformation was used due to unequal variances at the original scale. For Figures 2 and 3 the estimated means and confidence intervals of transformed variables were transformed back to the original scale.

\section{Labour consumption}

Total labour consumption per hectare was calculated for managing bare fallow, ley, inter-row hoe- 
Vol. 15 (2006): 444-458.

ing and stubble cultivation. The aim was to assess which weed control strategy required the least labour input. Calculation was done for a rectangular field $200 \mathrm{~m} \times 50 \mathrm{~m}$. The values for inter-row hoeing were based on the study of Lötjönen and Mikkola (1997). The values for bare fallow and stubble cultivation were based on the study of Peltonen and Vanhala (1992), and the values for ley were measured during the present study. Labour consumption for all methods was calculated using the "Standard time method" described in Peltonen and Vanhala (1992).

\section{Results}

\section{Sonchus arvensis density and biomass}

Several treatments had a significant effect on $S$. arvensis density and biomass (Figs 2-4). During the year of fallowing, bare fallow (Bf-Cer in 2001, Cer-Bf in 2002) reduced $S$. arvensis density and biomass considerably, destroying all or nearly all $S$. arvensis plants. The resultant effect of bare fallow was also very good, except on S. arvensis den-
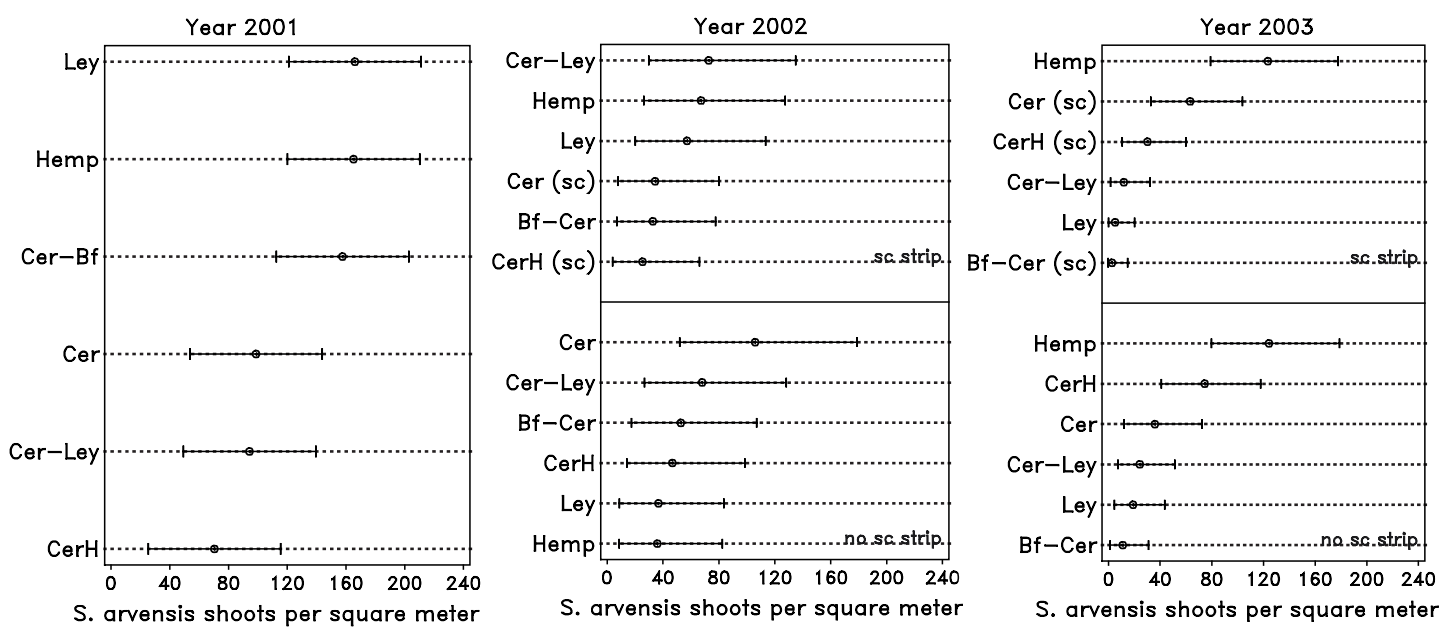

Fig. 2. Density (number of shoots $\mathrm{m}^{-2}$ ) of $S$. arvensis prior to cereal harvest, showing the estimated means and $95 \%$ confidence intervals of the means on the original scale. $n=5$, except for $\mathrm{Cer}_{\text {no sc }}$ in 2003 where $n=4$ (in figure Cer no sc $_{\text {outlier }}$ excluded, mean $=35.9$; if outlier included, mean $=66.0$ ). Due to zero or very low values, which indicate the superiority of these treatments while being not normally distributed, as assumed in the statistical tests, the following treatments were excluded from the analyses and graphs (mean \pm standard deviation in parentheses): Bf-Cer in $2001(0.40 \pm 1.26)$ and Cer-Bf in 2002 ( $0 \pm 0$ for both sc and no sc) and 2003 ( $2.40 \pm 3.58$ for sc, $3.20 \pm 3.35$ for no sc).

Statistically significant differences between means:

In 2001: Cer - Hemp $(\mathrm{P}=0.04)$, Cer - Ley $(\mathrm{P}=0.04)$.

In 2002: $(\text { Mean of Cer and CerH })_{\text {sc }}-(\text { Mean of Cer and CerH })_{\text {no sc }}(\mathrm{P}=0.04)$.

In 2003: Outlier included/excluded: $\mathrm{CerH}_{\mathrm{sc}}-\mathrm{CerH}_{\text {no sc }}(\mathrm{P}=0.08 / \mathrm{P}=0.04), \mathrm{Cer}_{\mathrm{sc}}-\mathrm{Bf}-\mathrm{Cer}_{\mathrm{sc}}(\mathrm{P}<0.001 / \mathrm{P}<0.001), \mathrm{Cer}_{\text {no sc }}$ - Bf-Cer $_{\text {no sc }}(\mathrm{P}<0.01 / \mathrm{P}=0.11)$, Hemp - Cer-Ley $(\mathrm{P}<0.001 / \mathrm{P}<0.001)$, Hemp - Ley $(\mathrm{P}<0.001 / \mathrm{P}<0.001), \mathrm{Cer}_{\text {no sc }}-$ $\mathrm{Hemp}_{\text {no sc strip }}(\mathrm{P}=0.08 / \mathrm{P}<0.005), \mathrm{Cer}_{\text {no sc }}-\mathrm{Ley}_{\text {no sc strip }}(\mathrm{P}=0.03 / \mathrm{P}=0.33)$.

Key to abbreviations: Cer $=$ Cereal, $\mathrm{CerH}=$ Cereal + hoeing, $\mathrm{Bf}=$ Bare fallow, $\mathrm{sc}=$ stubble cultivation. 
Vanhala, P. et al. Managing Sonchus arvensis using mechanical and cultural methods
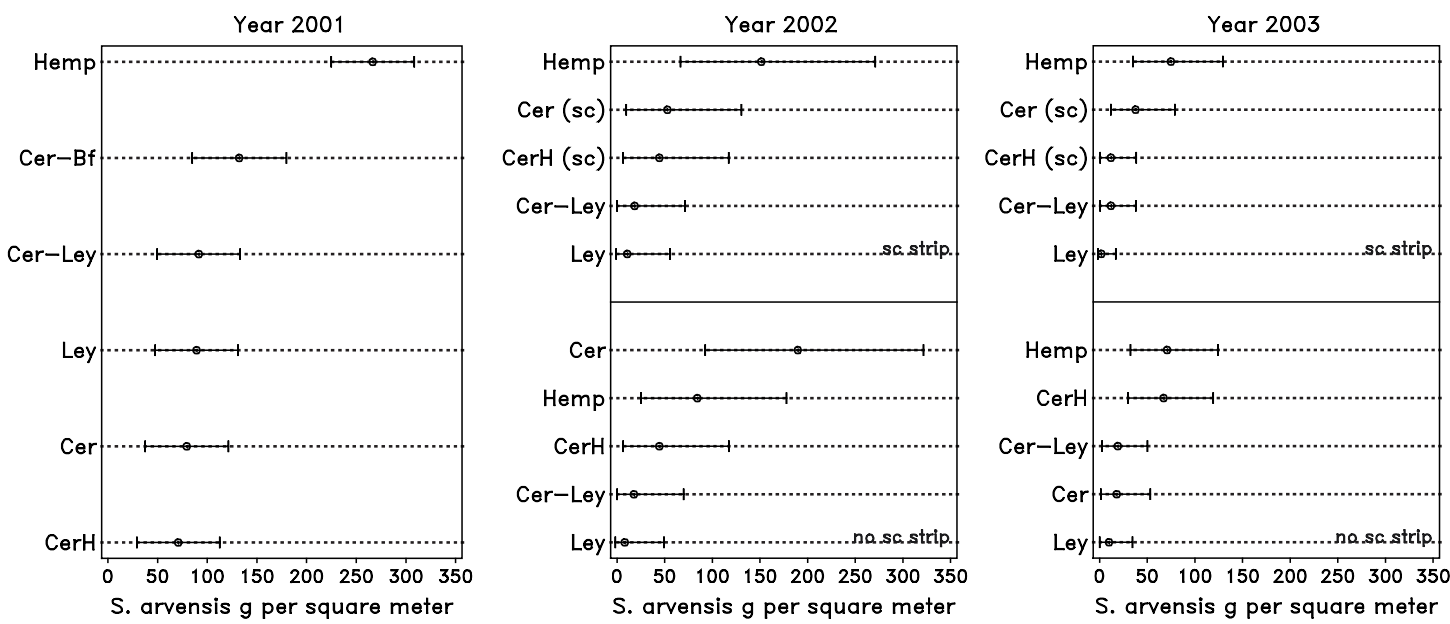

Fig. 3. Air-dry biomass $\left(\mathrm{g} \mathrm{m}^{-2}\right)$ of $S$. arvensis prior to cereal harvest, showing the estimated means and $95 \%$ confidence intervals of the means on the original scale. $\mathrm{n}=5$, except in Cer-Bf in 2001 and $\mathrm{Cer}_{\text {no sc }}$ in 2003 where $\mathrm{n}=4$. (In figure outliers excluded, Cer-Bf in 2001 and $\mathrm{Cer}_{\text {no sc }}$ in 2003 means 132.3 and 18.1; if outlier included, means 175.0 and 40.6, respectively) Due to zero or very low values, the following treatments were excluded from the analysis and graphs (mean \pm standard deviation in brackets): Bf-Cer in $2001(0 \pm 0), 2002$ ( $2.78 \pm 5.36$ for sc, $1.23 \pm 1.13$ for no sc) and $2003(0.48 \pm 0.89$ for sc, $4.47 \pm 4.34$ for no sc), and Cer-Bf in 2002 ( $0 \pm 0$ for both sc and no sc) and $2003(0.01 \pm 0.02$ for sc, $0.26 \pm 0.41$ for no sc).

Statistically significant differences between means:

In 2001: Outlier included/excluded: Cer - Hemp $(\mathrm{P}<0.001 / \mathrm{P}<0.001)$, Cer $-\mathrm{Cer}-\mathrm{Bf}(\mathrm{P}=0.02 / \mathrm{P}=0.10)$.

In 2002: $\mathrm{Cer}_{\text {sc }}-\mathrm{Cer}_{\text {no sc }}(\mathrm{P}<0.01), \mathrm{Cer}_{\text {no sc }}-\mathrm{CerH}_{\text {no sc }}(\mathrm{P}=0.02)$, Hemp - Cer-Ley $(\mathrm{P}=0.01)$, Hemp - Ley $(\mathrm{P}<0.01)$, $\mathrm{Cer}_{\text {no sc }}-\mathrm{Cer}_{-2 e y}$ no sc strip $(\mathrm{P}<0.005), \mathrm{Cer}_{\text {no sc }}-\mathrm{Ley}_{\text {no sc strip }}(\mathrm{P}<0.001)$.

In 2003: Outlier included/excluded: $\mathrm{CerH}_{\text {sc }}-\mathrm{CerH}_{\text {no sc }}(\mathrm{P}=0.03 / \mathrm{P}=0.02), \mathrm{Cer}_{\text {no sc }}-\mathrm{CerH}_{\text {no sc }}(\mathrm{P}=0.38 / \mathrm{P}=0.05), \operatorname{Hemp}$ - Cer-Ley $(\mathrm{P}<0.005 / \mathrm{P}<0.005)$, Hemp - Ley $(\mathrm{P}<0.001 / \mathrm{P}<0.001), \mathrm{Cer}_{\text {no sc }}-\mathrm{Hemp}_{\text {no s strip }}(\mathrm{P}=0.32 / \mathrm{P}=0.04)$.

Key to abbreviations: $\mathrm{Cer}=\mathrm{Cereal}, \mathrm{CerH}=\mathrm{Cereal}+$ hoeing, $\mathrm{Bf}=$ Bare fallow, $\mathrm{sc}=$ stubble cultivation.

sity in 2002 (Bf-Cer). Ley options (Cer-Ley, Ley) were also relatively efficient in reducing $S$. arvensis biomass, although they had little effect on $S$. arvensis density during the ley year(s). The resultant effects of the leys were good, especially the ley sown on bare soil (Ley). Inter-row hoeing (CerH) was not as effective and its efficacy varied somewhat. The resultant effect (in 2003) of hoeing was poor. The growth of hemp was unsatisfactory in the experimental field, and consequently $S$. arvensis biomass in hemp plots was relatively high both in hemp in 2001-02 and in subsequent spring wheat in 2003.

Stubble cultivation in the previous autumn reduced S. arvensis density in 2002 in standard and hoed cereal, and biomass in standard cereal com- pared with non-stubble-cultivated subplots. In 2003, stubble cultivation reduced the density and biomass of $S$. arvensis in hoed plots. The effect of stubble cultivation depended on treatment (standard or hoed cereal) in 2002 for S. arvensis biomass and, if an outlier in treatment Cer was not included in the analysis, in 2003 for density and biomass, showing better effect of stubble cultivation in standard cereal in 2002 and hoed cereal in 2003.

The rating of the treatments based on the resultant control effect in 2003 was: bare fallow > ley $>$ cereal with or without inter-row hoeing $>$ poor growth fibre hemp. Stubble cultivation was not directly comparable with the other treatments, but it seemed to fall between ley and inter-row hoeing. 
Vol. 15 (2006): 444-458.
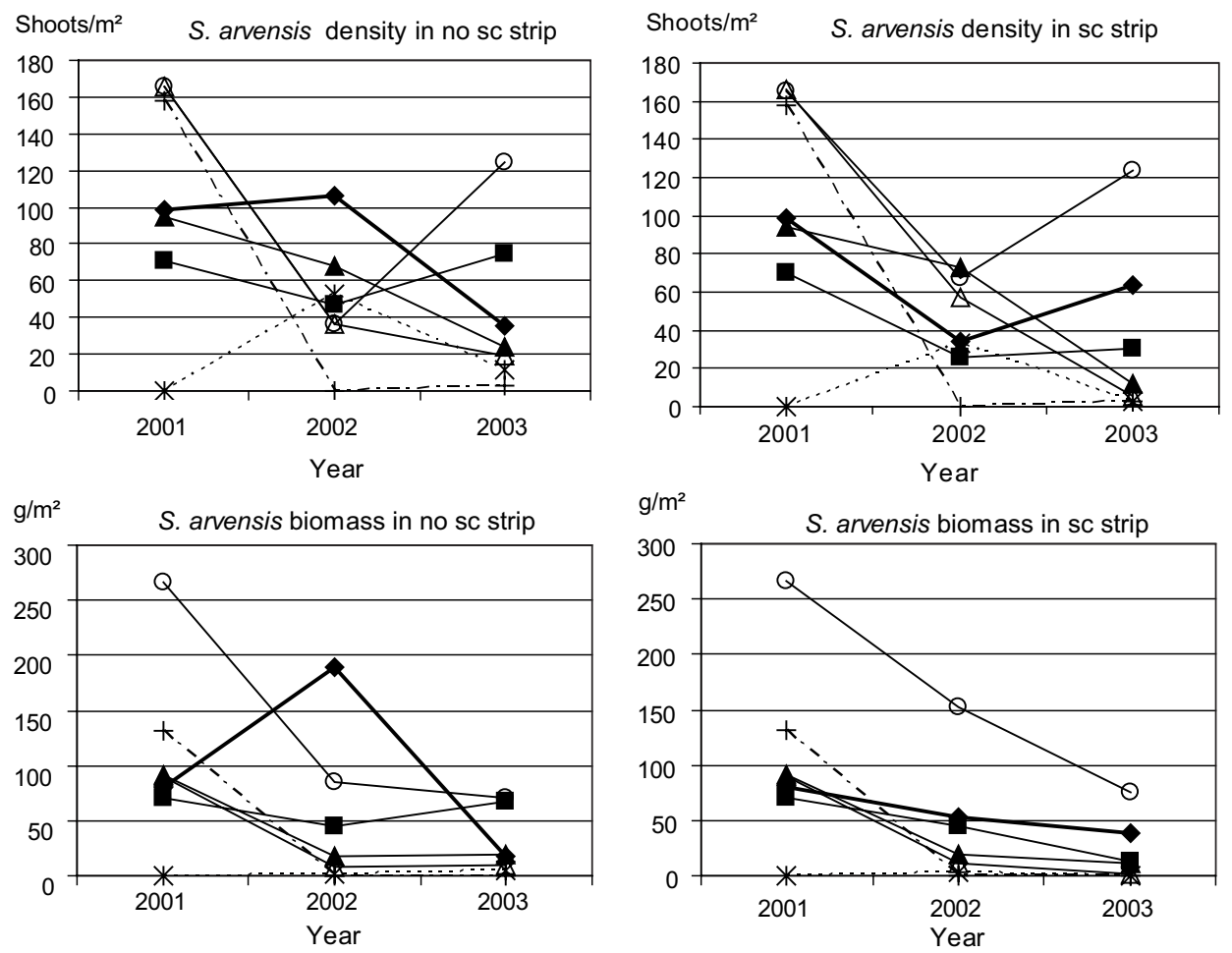

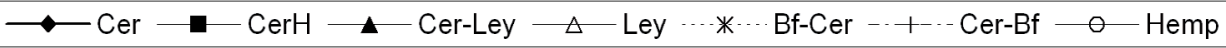

Fig. 4. Changes in Sonchus arvensis mean density and biomass across years.

\section{Other weeds}

In addition to $S$. arvensis, there were several other weed species present in the experimental field. In terms of biomass, the main species were Stachys palustris, Cirsium arvense, Elymus repens, Stellaria media (L.) Vill., Chenopodium album L., Fallopia convolvulus (L.) Á. Löve and Galeopsis spp. L. The total biomass of weeds other than $S$. arvensis was generally of the same magnitude as that of $S$. arvensis alone. The order of treatment effect according to the biomass of other weeds was somewhat different from that of $S$. arvensis. However, the most and least effective treatments were generally the same, except in 2003. In 2003 the other weeds in the plots Ley, Cer-Ley, and Bf-Cer produced abundant biomass while $S$. arvensis biomass was low.

\section{Crop biomass, density and yield}

Crop biomass in sample quadrats prior to cereal harvest was lowest in leys (Ley in 2001, Cer-Ley and Ley in 2002) (biomass low because ley had been mown three times) and hemp (poor growth) in 2001 and 2002, differing significantly from the standard cereal treatment (Fig. 5). Oat biomass was greater after bare fallow (Bf-Cer) than in the standard cereal treatment in the non-stubble-cultivated strip. In 2003, the previous year's bare fallow (Cer-Bf) and leys significantly increased wheat biomass compared with the standard cereal treat- 
Vanhala, P. et al. Managing Sonchus arvensis using mechanical and cultural methods
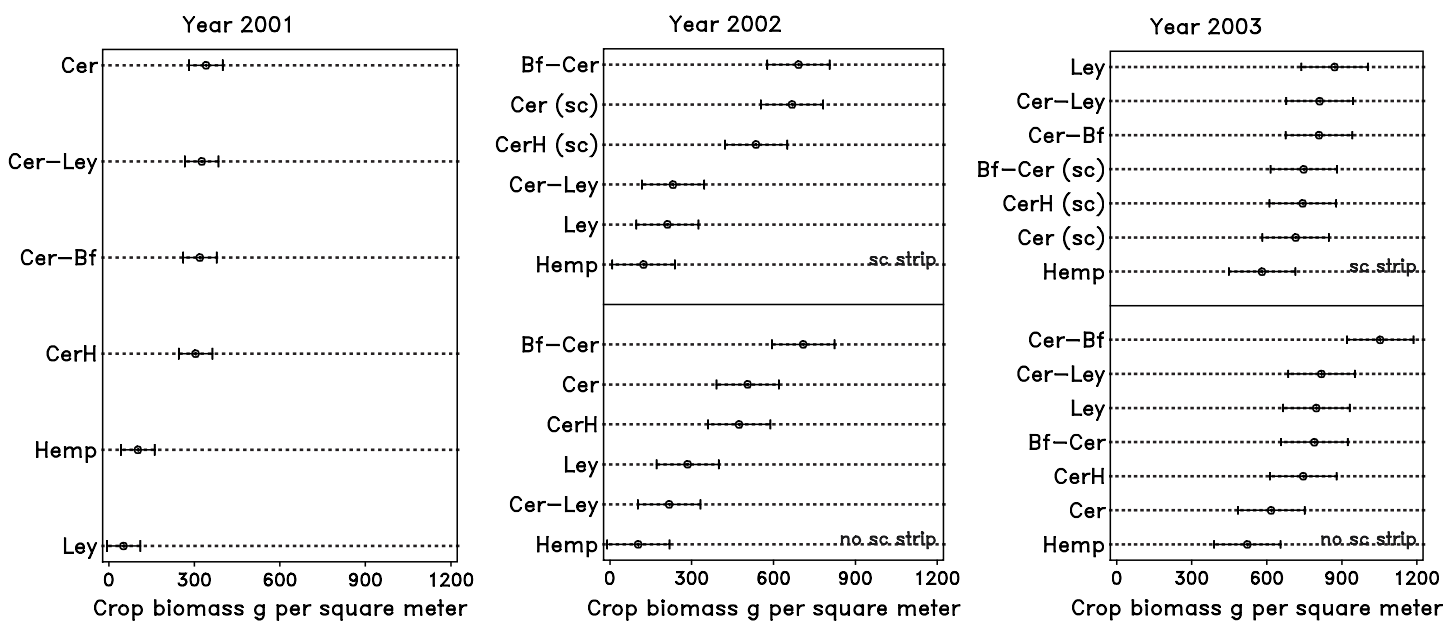

Fig. 5. Air-dry biomass $\left(\mathrm{g} \mathrm{m}^{-2}\right)$ of crop plants prior to cereal harvest, showing the estimated means and $95 \%$ confidence intervals of the means. $n=5$. Note: Ley yields harvested during the summer in 2002 are presented only in text.

Statistically significant differences:

In 2001: Cer - Hemp $(\mathrm{P}<0.001)$, Cer - Ley $(\mathrm{P}<0.001)$.

In 2002: (Mean of Cer and CerH) $)_{\text {sc }}-(\text { Mean of Cer and CerH })_{\text {no sc }}(\mathrm{P}=0.04)$, Cer-Ley - Hemp $(\mathrm{P}=0.04)$, Bf-Cer - Hemp $(\mathrm{P}<0.001)$, Ley $-\operatorname{Hemp}(\mathrm{P}=0.02), \mathrm{Cer}_{\text {no sc }}-\mathrm{Hemp}_{\text {no sc strip }}(\mathrm{P}<0.001), \mathrm{Cer}_{\text {no sc }}-\mathrm{Cer}_{-\mathrm{Ley}} \mathrm{nosc} \mathrm{strip}_{(}(\mathrm{P}<0.001), \mathrm{Cer}_{\text {no sc }}-\mathrm{Bf}-$ $\mathrm{Cer}_{\text {no sc strip }}(\mathrm{P}<0.01), \mathrm{Cer}_{\text {no sc }}-\mathrm{Ley}_{\text {no sc strip }}(\mathrm{P}<0.01)$.

In 2003: Hemp - Cer-Bf $(\mathrm{P}<0.001)$, Hemp - Cer-Ley $(\mathrm{P}<0.001)$, Hemp - Ley $(\mathrm{P}<0.001)$, Cer $_{\text {no sc }}-\mathrm{Cer}_{-\mathrm{Bf}} \mathrm{fosc}_{\text {strip }}(\mathrm{P}<$ $0.001), \mathrm{Cer}_{\text {no sc }}-\mathrm{Cer}_{-\mathrm{Ley}}$ no sc strip $(\mathrm{P}=0.03), \mathrm{Cer}_{\text {no sc }}-\mathrm{Ley}_{\text {no sc strip }}(\mathrm{P}=0.05)$.

Key to abbreviations: $\mathrm{Cer}=$ Cereal, $\mathrm{CerH}=\mathrm{Cereal}+$ hoeing, $\mathrm{Bf}=$ Bare fallow, $\mathrm{sc}=$ stubble cultivation.

ment. Stubble cultivation in the previous autumn increased cereal biomass in 2002 (Cer, CerH), but had no significant effect in 2003.

Cereal density was not significantly affected by the treatments, not even by wider row spacing in hoed plots, except in 2002, when oats produced on average more shoots after (non-stubble-cultivated) bare fallow (642 shoots per $\left.\mathrm{m}^{2}\right)$ than in nonstubble-cultivated standard (477 shoots per $\mathrm{m}^{2}$ ) or hoed cereal $\left(447\right.$ shoots per $\left.\mathrm{m}^{2}\right)$ treatment $(\mathrm{P}=$ 0.0021 and 0.0005 , respectively). Hemp density was 92 plants per $\mathrm{m}^{2}$ in 2001 and only 45 plants per $\mathrm{m}^{2}$ in 2002.

The mean height of cereals (pooled across different treatments) was $32 \mathrm{~cm}$ for barley, $74 \mathrm{~cm}$ for oats and $77 \mathrm{~cm}$ for wheat, while the standard stem heights of the varieties used are 70,87 and $77 \mathrm{~cm}$, respectively, according to Official variety trials of MTT 1995-2002 (Kangas et al. 2003). The mean height of hemp was $61 \mathrm{~cm}$ in 2001 and $81 \mathrm{~cm}$ in 2002.

The treatments had some effect on cereal (Fig. 6 ) and ley yields either directly or through $S$. arvensis biomass. In 2001 inter-row hoeing (CerH) resulted in higher yields than the standard cereal treatment.

The ley yields in treatments Cer-Ley and Ley in 2002 were significantly different only in the first mowing on 20 June 2002, when Ley produced higher $(\mathrm{P}<0.001, \mathrm{n}=5)$ yield (estimated mean $3266 \mathrm{~kg} \mathrm{ha}^{-1}$ dry matter) than Cer-Ley $(2512 \mathrm{~kg}$ $\mathrm{ha}^{-1}$ dry matter). The ley yields in the second mowing on 2 August were 2430 and $2456 \mathrm{~kg} \mathrm{ha}^{-1}$ and in the third mowing on 20 September 1716 and 1790 $\mathrm{kg} \mathrm{ha}^{-1}$ dry matter, in Ley and Cer-Ley, respectively. All mown crop and weed plants were included in ley yields. In 2003, wheat yield after the failed fibre hemp crop was significantly lower, and after 
Vol. 15 (2006): 444-458.
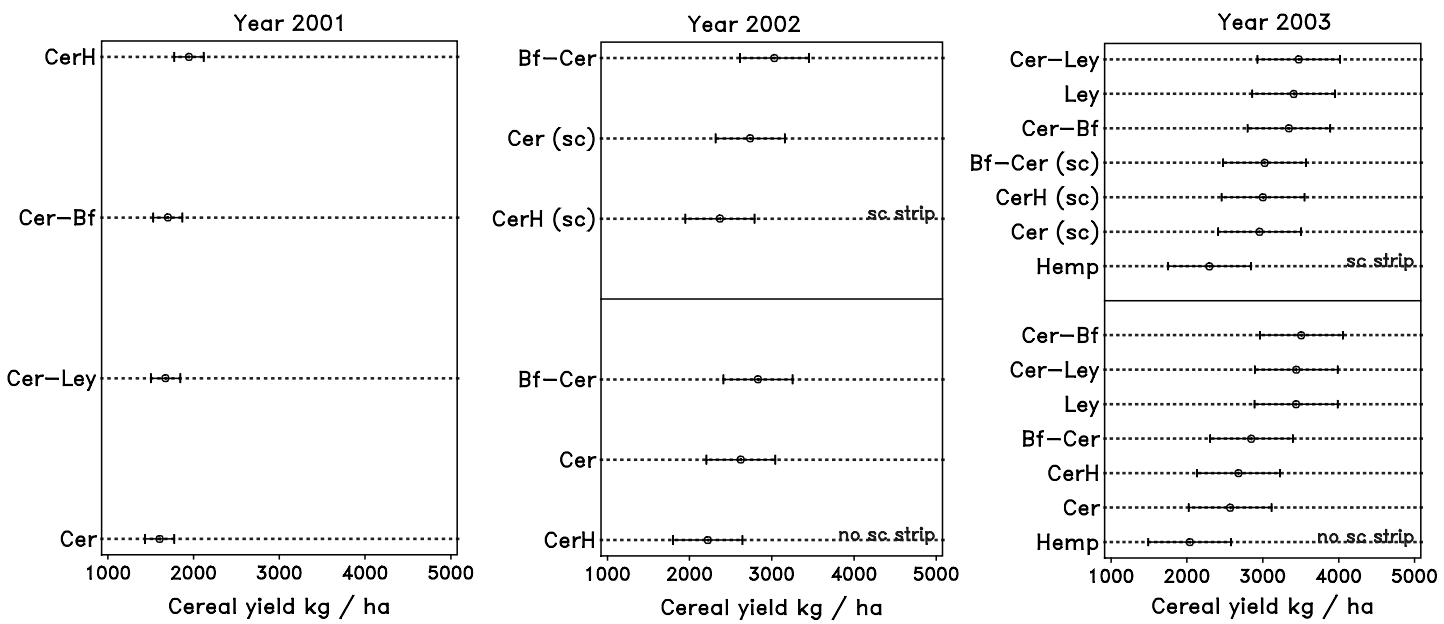

Fig. 6. Cereal yields (converted to $14 \%$ moisture), showing the estimated means and $95 \%$ confidence intervals of the means. $\mathrm{n}=5$.

Statistically significant differences:

In 2001: Cer - CerH $(\mathrm{P}<0.01)$.

In 2002 no statistically significant differences.

In 2003: Hemp - Cer-Bf $(\mathrm{P}<0.001)$, Hemp - Cer-Ley $(\mathrm{P}<0.001)$, Hemp - Ley $(\mathrm{P}<0.001), \mathrm{Cer}_{\text {no sc }}-\mathrm{Hemp}_{\text {no sc strip }}(\mathrm{P}=$ $0.02), \mathrm{Cer}_{\text {no sc }}-\mathrm{Cer}^{-\mathrm{Bf}_{\text {no sc strip }}}(\mathrm{P}<0.001), \mathrm{Cer}_{\text {no sc }}-\mathrm{Cer}^{-L_{\text {ne sc strip }}}(\mathrm{P}<0.001), \mathrm{Cer}_{\text {no sc }}-\mathrm{Ley}_{\text {no sc strip }}(\mathrm{P}<0.001)$.

Key to abbreviations: $\mathrm{Cer}=\mathrm{Cereal}, \mathrm{CerH}=\mathrm{Cereal}+$ hoeing, $\mathrm{Bf}=$ Bare fallow, $\mathrm{sc}=$ stubble cultivation .

the previous year's bare fallow and leys significantly higher than after the standard cereal treatment.

\section{Labour consumption}

Total labour consumption per hectare for different treatments in the experiment are shown in Table 2. Naturally the working width and the driving speed of the machines had a substantial effect on this measure. For example, in commercial fields seedbed cultivators are commonly wider than $3 \mathrm{~m}$. Inter-row hoeing needs more adjustment and malfunctions occur more frequently than for other methods. In the study of Lötjönen and Mikkola (1997) malfunctioning and adjusting time was 820 minutes per hectare. In very tall weed and crop conditions twenty minutes per hectare was required. Eight minutes per hectare represents malfunction and adjustment time under normal conditions. Therefore, ten minutes per hectare was used in Table 2. Perennial weeds can grow tall and they can easily block the hoe. In the present study the experimental plots were only $25 \mathrm{~m}$ long and blocking did not occur.

\section{Discussion}

\section{Effect of treatments on Sonchus arvensis}

Bare fallowing was an efficient mechanical method for controlling S. arvensis. On the other hand, it is also an expensive method in terms of labour and fuel consumption and lost yield during the year of fallowing. Therefore, bare fallowing should be carried out carefully to maximize the weed control effect. There are two possible strategies: 1) drying the roots when the weather is sunny (1-2 cultivation per week) and 2) exhausting the roots by cultivating at compensation point (Håkansson 1969). 
Vanhala, P. et al. Managing Sonchus arvensis using mechanical and cultural methods

Table 2. Total labour input per hectare for different weed control treatments. The values are calculated for a field $200 \mathrm{~m} \times$ $50 \mathrm{~m}$. The values were based on the studies of Peltonen and Vanhala (1992) and Lötjönen and Mikkola (1997), and the measurements done during the present study.

\begin{tabular}{|c|c|c|c|c|}
\hline \multirow[t]{3}{*}{ Quantity and unit } & \multicolumn{4}{|c|}{ Treatment and machine (below) } \\
\hline & Bare fallow & Ley & Hoeing & Stubble cultivation \\
\hline & Seedbed cultivator & Flail mower & Inter-row hoe & Seedbed cultivator \\
\hline Working width, $\mathrm{cm}$ & 300 & 300 & 300 & 300 \\
\hline Driving speed, $\mathrm{km} \mathrm{h}^{-1}$ & 9.0 & 6.0 & 5.0 & 9.0 \\
\hline Driving time, $\min \mathrm{ha}^{-1}$ & 23.4 & 35.1 & 40.0 & 23.4 \\
\hline Turning time, $\min$ ha $^{-1}$ & 4.5 & 4.5 & 4.5 & 4.5 \\
\hline Resting time, $\min \mathrm{ha}^{-1}$ & 2.2 & 3.2 & 3.5 & 2.2 \\
\hline Malfunctioning and adjusting, $\min \mathrm{ha}^{-1}$ & 2.7 & 3.4 & 10.0 & 2.7 \\
\hline Total time per pass, min ha-1 & 32.8 & 46.1 & 58.1 & 32.8 \\
\hline Passes per summer & 6 & 3 & 3 & 2 \\
\hline Total time per summer, $\mathrm{h} \mathrm{ha}^{-1}$ & 3.3 & 2.3 & 2.9 & 1.1 \\
\hline
\end{tabular}

The latter strategy, which was used in this study, probably gives better results than the former one in wet summers, when drying of root fragments on the soil surface is slow. Usually bare fallowing requires 6-8 passes/summer under Finnish conditions, so there is a risk of damaging soil structure through compression.

Mowing the ley was effective in reducing $S$. arvensis shoot biomass; in this study leys were mown three times during the summer. This should also reduce the reproductive capacity of the roots (Håkansson 1969), and consequently reduce weed infestation in subsequent years, as occurred in our study. In our study there was only one actual ley year, but the resultant effect of leys on S. arvensis was encouraging. Prolonging the ley by some additional years would probably increase the control effect. The advantages of a well over-wintered ley compared with spring-sown annual crops are fast initial growth in spring, high growth density and fast regrowth after mowing. Populations of perennial weeds such as $S$. arvensis and Cirsium arvense cannot easily adapt to frequent mowing or grazing (Gummesson 1992, Håkansson 1995). The suggestions for optimum timing and frequency of mowing vary from 3-4 cuts per summer at 4-6 leaves in pure stands (Håkansson 1969) to 2-3 mowings during summer or one late mowing at seed stage in green fallow (Aquilina and Clarke 1994). Further studies on the effect of crop competition on the optimum timing of mowing would be useful.

The higher yield in 2002 of first mowing of ley established on bare soil (Ley) than on ley under cereal (Cer-Ley) may reflect the effect of method of establishment. Plants sown on bare soil can accumulate greater carbohydrate reserves for overwintering as there is no competition from the cereal, and - in this experiment - maybe also less competition from $S$. arvensis (which was somewhat controlled by mowing during the year of establishment, 2001). After the first mowing there were no differences in ley yield, but the differences in weed control as influenced by the method of ley crop establishment is worth noting.

In our study, stubble cultivation in autumn in many cases reduced $S$. arvensis infestation during the following year. In previous studies stubble cultivation had little effect on $S$. arvensis, although it controlled E. repens successfully (e.g. Fogelfors and Boström 1998). This is attributed to the fact that the root buds of $S$. arvensis are largely dormant in autumn, around late August and/or in September-October (Håkansson 1969, Håkansson and Wallgren 1972, Fogelfors et al. 2003). However, the fragmentation of roots and their burial weakens 
Vol. 15 (2006): 444-458.

the competitive capacity of the plants during the next growing season (Gummesson 1992, Håkansson 1995). Stubble cultivation may also enhance decay of root fragments. Moreover, it is the smallest and often the first plants, either from seeds or small root fragments, that are the most likely to remain intact at harvest as all their leaves can be situated below the cutting height. If these small plants are not controlled by stubble cultivation, for example, they will accumulate root reserves for the coming seasons. However, wet conditions prevent stubble cultivation; e.g. in a Finnish study by Salonen (1992) this happened during two autumns out of six.

Inter-row hoeing reduces weed growth, thus leaving more space for the crop. This may have been the reason for higher barley yields with interrow hoeing than without hoeing in 2001. It is difficult to explain why hoeing did not improve oats yield in 2002, but the fact that hoeing was done three times in 2001, but only twice in 2002, may have contributed to the difference in results in different years. Density of cereals was similar despite different row spaces. Inter-row hoeing also loosens the soil and allows more air to reach the roots, which can improve plant growth (Väisänen et al. 2004). Inter-row hoeing is more useful when weeds are abundant. If weeds are scarce, there may be little advantage in mechanical weed control (Rasmussen and Svenningsen 1995, Lötjönen and Mikkola 2000). Inter-row hoeing controls weeds well between the rows, but it does not control perennial weeds in rows. The weed control effect of hoeing could be intensified by extending the row spacing. For instance, if we assume that the unhoed strip is $7 \mathrm{~cm}$ wide and the row spacing is $12.5,18,25$ or 30 $\mathrm{cm}, 44,61,72$ or $77 \%$ of the field surface can be hoed respectively. On the other hand, crop yield and competition effect have been reported to decrease due to wide row spacing (Håkansson 1984, Johansson 1998, Melander et al. 2001).

\section{Crop species}

Fibre hemp was far less competitive than expected. Fibre hemp failed in the trial field, thus represent- ing a poorly competitive crop rather than a strongly competitive one. As a poorly growing crop it did not suppress $S$. arvensis to the same extent as the other crops did, thus showing the disadvantage of poor crop competition in the absence of direct weed control. Additionally, as hemp was harvested later than cereals, S. arvensis had the opportunity to accumulate root reserves in the autumn. It must be emphasized that the growth of hemp in this experiment was exceptionally poor.

Based on the resultant effects, the treatments that promoted the highest wheat yields in 2003 (Cer-Bf, Ley, Cer-Ley) were also among those that reduced $S$. arvensis most. The higher yields may have been due to both reduced $S$. arvensis competition and increase in available nutrients. Bare fallowing releases nutrients from the soil (Becker and Böhrnsen 1994), while red clover and other legumes introduce nitrogen into the soil (Robson et al. 2002).

\section{Role of other weeds}

As the biomass of other weeds generally followed the same pattern as the biomass of $S$. arvensis, the other weeds probably played no major role in defining the order of treatments either in terms of $S$. arvensis, crop densities or biomass. One can expect that most actions aimed at reducing $S$. arvensis will in the short term also reduce weeds in general. In the long term, some weed species adapted to specific situations may however increase, e.g. Elymus repens may increase in perennial leys (Håkansson 1995). On the other hand, improved growing conditions may increase the growth of other (annual) weeds as well as the crop, as was recorded in 2003 in wheat after the leys.

\section{Labour consumption of different methods}

Bare fallow seems to have the highest labour requirement. No crop yield can be produced during a fallow year and the method can harm soil structure. However, according to these results, bare fallow is the most effective method for managing $S$. 
Vanhala, P. et al. Managing Sonchus arvensis using mechanical and cultural methods

arvensis. Ley with mowing provides a grass yield and has a fertilisation effect on the next crop. The present study showed that this method had quite a good effect on controlling $S$. arvensis and it can be the most economical choice in many cases. Inter-row hoeing makes it possible to produce cereals or other crops while controlling weeds. Interrow hoeing controlled perennial weeds moderately well in the year of application, but in the subsequent year there was no effect. Stubble cultivation was associated with the lowest labour requirement and it caused a decrease in S. arvensis infestation levels in many cases. It also made crop production possible during the summer. In organic farming, a ley or catch crop is often sown with cereals and in that case stubble cultivation is not possible.

\section{Conclusions}

Overall, the results of this study suggest that the following management measures could be implemented in order to suppress $S$. arvensis infestation: 1) Mowing the plants in crops such as leys to suppress $S$. arvensis biomass production. It would be profitable to have a perennial, regularly mown green fallow or silage ley in the crop rotation. 2) A crop should be selected that is competitive not only generally, but also under the conditions of a given field. 3) Bare fallow is an effective way to reduce $S$. arvensis infestation, but it is costly in terms of labour and fuel and there is no crop yield. If the rotation lacks perennial leys or similar crops, bare fallowing may be necessary in systems where chemical weed control is not used. 4) Mechanical control in the crop stand is also possible; inter-row hoeing in cereals seems to suppress $S$. arvensis, if it is done 2-3 times during the growing season. 5) Stubble cultivation in autumn may be used in order to reduce $S$. arvensis vigour in the next season. The advantages and synergy of different control measures, as well as long-term effects, should be taken into account when planning crop rotations to control S. arvensis.
In further research, more information should be obtained on $S$. arvensis development to establish the optimal timing for each control method. In addition, the effect and importance of tillage methods on weed control should be researched. Nowadays there is a trend towards minimum tillage. However, the importance of cultivation as a perennial weed control method should be borne in mind when new machinery is developed. At present there are many new machine types suitable for stubble cultivation and bare fallow tillage that should be evaluated in field experiments.

In conclusion, overcoming $S$. arvensis infestation requires determined use of crop rotation in conjunction with cultural and mechanical means. It is also necessary to take a long-term view of the problem and plan weed management accordingly. Additionally, tillage and other machinery should be developed with a view to managing perennial weeds.

Acknowledgements. We wish to thank Eira-Maija Tanni, Riina Paju, Anne Muotila and co-workers at MTT for careful observations throughout the study. The Ministry of Agriculture and Forestry is gratefully acknowledged for financial support. We thank Dr Jonathan Robinson for linguistic revision of the paper.

\section{References}

Aquilina, M. \& Clarke, J.H. 1994. Effect of cutting date and frequency on perennial broad-leaved weeds on setaside. Arable farming under CAP reform. Aspects of Applied Biology 40: 541-546.

Becker, K. \& Böhrnsen, A. 1994. Wirkungen mechanischer Pflegemaßnahmen auf die Unkrautabundanz und die $\mathrm{N}$-mineralisation im Boden. Summary: Effects of mechanical treatments on weed abundance and $\mathrm{N}$-mineralization in the soil. Zeitschrift für Pflanzenkrankheiten und Pflanzenschutz, Sonderheft 14. p. 315-324.

Finnish Meteorological Institute 2004. Weather data obtained from the Intranet of MTT. Cited 3 March 2004.

Fogelfors, H. \& Boström, U. 1998. Anpassa höstbearbetningen efter ogräsfloran. Fakta Jordbruk. Nr. 8/1998. Uppsala: Sveriges lantbruksuniversitet. 4 p. (in Swedish).

Fogelfors, H., Brandsæter, L., Graglia, E., Vanhala, P., Salonen, J. \& Håkansson, S. 2003. Dormancy of vegetative reproduction in some perennial weeds. In: Nieme- 
Vol. 15 (2006): 444-458.

läinen, O. \& Topi-Hulmi, M. (eds.). Proceedings of the NJF's 22nd congress 'Nordic Agriculture in global perspective', 1-4 July 2003, Turku, Finland. Jokioinen: MTT, NJF. p. 97.

Gomez, K.A. \& Gomez, A.A. 1984. Statistical procedures for agricultural research. 2nd edition. New York, NY: John Wiley \& Sons. 680 p.

Gummesson, G. 1992. Ogräsbekämpning i olika odlingssystem. Aktuellt från lantbruksuniversitetet 404. Uppsala: Sveriges lantbruksuniversitet. 22 p. (in Swedish).

Håkansson, S. 1969. Experiments with Sonchus arvensis L. 1. Development and growth, and the response to burial and defoliation in different developmental stages. Lantbrukshögskolans annaler 35: 989-1030.

Håkansson, S. 1984. Row spacing, seed distribution in the row, amount of weeds - influence on production in stands of cereals. In: Weeds and weed control. 25th Swedish Weed Conference. Vol. 1 Reports. p. 17-34.

Håkansson, S. 1995. Ogräs och odling på åker. Aktuellt från lantbruksuniversitetet nro 437/438 Mark-växter. Uppsala: Sveriges lantbruksuniversitet. 70 p. (in Swedish).

Håkansson, S. \& Wallgren, B. 1972. Experiments with Sonchus arvensis L. 2. Reproduction, plant development and response to mechanical disturbance. Swedish Journal of Agricultural Research 2: 3-14.

Holm, L., Doll, J., Holm, E., Pancho, J. \& Herberger, J. 1997. World weeds. Natural histories and distribution. New York: John Wiley \& Sons. 1129 p.

Johansson, D. 1998. Radhackning med och utan efterredskap i stråsäd. Slutrapport för fältförsök 1995-1997. Institutionen för markvetenskap. Rapporter från jordbearbetningsavdelningen $\mathrm{nr}$. 94. Uppsala: Sveriges lantbruksuniversitet. 49 p. (in Swedish, summary in English).

Kangas, A., Laine, A., Niskanen, M., Salo, Y., Vuorinen, M., Jauhiainen, L. \& Mäkelä, L. 2003. Virallisten lajikekokeiden tulokset 1995-2002. (Results of official variety trials 1995-2002). Agrifood Research Working papers 29. Jokioinen: MTT Agrifood Research Finland. 234 p. Available on the Internet: http://www.mtt.fi/mtts/pdf/ mtts29.pdf

Lemna, W.K. \& Messersmith, C.G. 1990. The biology of Canadian weeds. 94. Sonchus arvensis L. Canadian Journal of Plant Science 70: 509-532.

Lötjönen, T. \& Mikkola, H. 1997. Rikkakasvien torjunta viljoista riviväliharauksella. Maatalouden tutkimuskeskus. Vakolan tiedote 74/97. Vihti: Maatalousteknologian tutkimuslaitos. 22 p. (in Finnish).

Lötjönen, T. \& Mikkola, H. 2000. Three mechanical weed control techniques in spring cereals. Agricultural and Food Science in Finland 9: 269-278.
Melander, B., Rasmussen, K., Rasmussen, I.A. \& Jørgensen, M.H. 2001. Radrensning med og uden ukrudtsharvning i vintersæd om foråret i samspil med forskellige dyrkningsfaktorer. Abstract: Row hoeing followed by weed harrowing in winter cereals in spring under the influence of different cropping factors. 18th Danish Plant Protection Conference 1. DJF-Rapport, - Markbrug. Nr. 40. Tjele: Danmarks JordbrugsForskning. p. 211-225.

Milliken, G.A. \& Johnson, D.E. 1984. Analysis of messy data - Volume I: Designed experiments. New York, NY: Van Nostrand Reinhold. 473 p.

Mukula, J. 1974. Weed competition in spring cereal fields in Finland. Forskning og forsøk i landbruket 25: 585-592.

Peltonen, M. \& Vanhala, A. 1992. Maatalouden työnormit. Kasvintuotannon yleiset työt. Työtehoseuran maataloustiedote 421. Helsinki: Työtehoseura. 8 p. (in Finnish).

Rasmussen, J. \& Svenningsen, T. 1995. Selective weed harrowing in cereals. Biological Agriculture and Horticulture 12: 29-46.

Robson, M.C., Fowler, S.M., Lampkin, N.H., Leifert, C., Leitch, M., Robinson, D., Watson, C.A. \& Litterick, A.M. 2002. The agronomic and economic potential of break crops for ley/arable rotations in temperate organic agriculture. Advances in Agronomy 77: 369-427.

Salonen, J. 1992. Propagation, impact and management of Elymus repens in continuous cereal cultivation. In: Richardson, R.G. (ed.). Proceedings of the first international weed control congress, Melbourne, 17-21 February 1992 . Volume 2 . Melbourne: The Weed Science Society of Victoria Inc. p. 454-456.

Salonen, J. \& Hyvönen, T. 2002. Perennial weeds in conventional and organic cropping of spring cereals in Finland. Zeitschrift für Pflanzenkrankheiten und Pflanzenschutz, Sonderheft 18. p. 519-525.

Salonen, J., Hyvönen, T. \& Jalli, H. 2001a. Weed flora in organically grown spring cereals in Finland. Agricultural and Food Science in Finland 10: 231-242.

Salonen, J., Hyvönen, T. \& Jalli, H. 2001b. Weeds in spring cereal fields in Finland - a third survey. Agricultural and Food Science in Finland 10: 347-367.

SAS Institute Inc. 1999. SAS OnlineDoc $®$, Version 8. Cary, NC: SAS Institute Inc.

Väisänen, J., Forsman, K., Kakriainen-Rouhiainen, S., Lötjönen, T. \& Avikainen, H. 2004. Kasvuvoimaa luomuohralle. Abstract: Growth vigour for organic barley. Agrifood Research Reports 52. Jokioinen: MTT Agrifood Research Finland. 88 p. (in Finnish).

Zollinger, R.K. \& Kells, J.J. 1991. Effect of soil pH, soil water, light intensity, and temperature on perennial sowthistle (Sonchus arvensis L.). Weed Science 39: 376-384. 


\title{
SELOSTUS
}

\section{Peltovalvatin torjunta mekaanisin ja viljelyteknisin menetelmin}

\author{
Petri Vanhala, Timo Lötjönen, Timo Hurme ja Jukka Salonen \\ MTT Kasvintuotannon tutkimus
}

Peltovalvatti (Sonchus arvensis L.) on viime vuosina runsastunut pelloillamme, erityisesti luomuviljelyssä. Tämän kestorikkakasvin kemikaaliton torjunta ei ole helppoa. Viljelykasvien kilpailu ja viljelytekniset toimet, kuten niitto, haraus ja avokesannointi, tarjoavat joitakin mahdollisuuksia kestorikkakasvien hallintaan.

Peltovalvatin mekaanisen ja viljelyteknisen torjunnan tutkimiseksi perustettiin vuonna 2001 kolmivuotinen kenttäkoe Vihtiin. Koe sijoitettiin savimaalle, pellolle, joka on ollut siirtymävaiheen jälkeen luomuviljelyssä vuodesta 1997 ja jolla kasvoi runsaasti peltovalvattia. Koe oli järjestetty strip-plot-asetelman mukaisesti, sänkimuokkaus horisontaalisena faktorina ja käsittely vertikaalisena faktorina. Kerranteita oli viisi. Koekenttä lannoitettiin vuosittain sianlietteellä (N 60-100 kg/ha) viljan kylvöaikaan. Käsittelyt koostuivat eri viljelykasveista ja viljelytoimenpiteistä, mukaan lukien: kevätvilja (v. 2001 ohra, v. 2002 kaura) riviväliharauksella tai ilman, kuituhamppu, avokesanto sekä timotei-puna-apila -nurmi, jota niitettiin. Vuonna 2003 koko kenttä kylvettiin kevätvehnälle. Ennen viljan puintia otettiin kasvinäytteet, joista määritettiin valvatin ja viljelykasvien lukumäärä ja kuivapaino sekä muiden rikkakasvien kuivapaino. Nurmien ja viljojen sadot mitattiin.

Useat viljelykasvi-torjuntakäsittely -yhdistelmät vähensivät peltovalvattia jatkuvaan viljakiertoon nähden. Avokesannointi torjui tehokkaimmin valvattia, ja niitetty nurmi oli jälkivaikutukseltaan lähes yhtä tehokas. Käsittelyjen paremmuusjärjestys oli viimeisenä koevuonna todetun torjunnan jälkivaikutuksen perusteella seuraava: avokesanto $>$ nurmi $>$ viljan riviväliharaus, vilja $>$ huonosti kasvanut kuituhamppu. Sänkimuokkaustulokset eivät olleet suoraan verrattavissa muihin käsittelyihin, mutta se näyttäisi sijoittuvan nurmen ja riviväliharauksen väliin. Käsittelyillä oli jonkin verran vaikutusta viljelykasvien satoihin; nurmella ja avokesannolla oli edullisimmat vaikutukset seuraavan vuoden satoon. Työnmenekki oli suurin avokesannoinnissa, seuraavaksi tulivat riviväliharaus, nurmen niitto, ja pienimmällä työnmenekillä sänkimuokkaus.

Tulosten perusteella näyttää siltä, että valvattia voitaisiin pitää kurissa seuraavilla kemikaalittomilla menetelmillä: 1) Nurmen niittäminen näyttää tehoavan peltovalvattiin. Tämän takia olisi tärkeää, että viljelykierrossa olisi monivuotinen niitettävä viherkesanto tai säilörehunurmi. 2) Viljelykasviksi tulisi kylvää kasvi, joka on kilpailukykyinen kyseisen lohkon oloissa. 3) Avokesanto on tehokas mutta kallis tapa vähentää valvattia. Se voi kuitenkin olla tarpeen, jos viljelykiertoon ei sisälly niitettäviä nurmia eikä kemiallista torjuntaa haluta käyttää. 4) Myös mekaaninen torjunta viljelykasvikasvustossa on mahdollista; riviväliharaus vähentää valvattia riviväleissä, joskaan viljariveissä kasvaviin kestorikkakasveihin haralla ei päästä käsiksi. 5) Syksyistä sänkimuokkausta voidaan käyttää heikentämään valvatin elinvoimaa seuraavana kasvukautena. Eri torjuntamenetelmien hyödyntämismahdollisuudet tulee ottaa huomioon viljelykiertoja suunniteltaessa. 